\author{
Magdalena DOBRZAŃSKA ${ }^{1}$ \\ Pawel DOBRZAŃSKI ${ }^{2}$ \\ Mirosław ŚMIESZEK ${ }^{3}$
}

\title{
MODERN LOGISTICS IN HEALTH SERVICE
}

The primary task of all hospitals is to improve the health of patients. In a typical hospital a large number of people perform logistics operations often without being aware of it. The aging of the population, particularly evident in Europe, contributes to the increase in the workload of the healthcare system. To ensure the desired level of healthcare services some services such as logistics must be effectively coordinated to ensure the quality and continuity of care.

Logistics in medical activities is a field that is not visible to the patient, but directly affects the quality of health services, which is an important area of interest for the healthcare organization. In most cases, hospital logistics has relied so far on the selection of appropriate suppliers in different areas of activity, starting from the supply of drugs, equipment, laundry, through transportation to the transplant ending up with the food catering. Such an approach in a self- management in most cases had various effects very often totally inefficient.

In the recent period it has been observed the development of logistics services in the medical activity which applies the most advanced technological achievements among them information technologies supported by management, maintenance-free means of transport, automated transport, technologies of automatic identification.

In the paper the modern forms of logistics used in healthcare were presented. The benefits of these solutions were shown. These benefits may be of two types. On the one hand they reduce the costs associated with the operation of the hospital, on the other one they increase security, reliability and availability at any time. A significant share of attention in the article is devoted to the supply chains based on modern means of transport. These measures are used to transport people and materials.

Keywords: health service, health protection, logistics in medical activity, logistics services.

\section{INTRODUCTION}

The aging of the population particularly evident in Europe contributes to the increase in the workload of the healthcare system. To ensure the desired level of healthcare services some services such as logistics must be effectively coordinated to ensure the quality and continuity of care. Statistics show that the number of patients in the hospital is growing very rapidly especially in Western countries [8]. It greatly increases the load of logistics functions.

\footnotetext{
1 Magdalena Dobrzańska, PhD, Eng., Department of Qualitative Methods, the Rzeszow University of Technology, Rzeszow, al. Powstańców Warszawy 8, 35-959 Rzeszów, tel. 17 8651317, e-mail: md@prz.edu.pl. (Corresponding Author).

${ }^{2}$ Paweł Dobrzański, PhD, Eng. Department of IT in Management, the Rzeszow University of Technology, , Rzeszow, al. Powstańców Warszawy 8, 35-959 Rzeszów, tel. 17 8651895, e-mail: pd@ @rz.edu.pl.

${ }^{3}$ Mirosław Śmieszek, DSc, PhD, Eng., Associate Professor, the Rzeszow University of Technology, Rzeszow, al. Powstańców Warszawy 8, 35-959 Rzeszów, tel. 17 8651593, e-mail: msmieszk@prz.edu.pl.
} 
Logistics in medical activities is a field that is not visible to the patient, but directly affects the quality of health services, which is important for the healthcare area. Most hospital logistics has consisted so far in the selection of appropriate suppliers in different areas of activity, ranging from the supply of drugs, equipment suppliers, laundry, transportation to the transplant until the food catering. Such an approach in a selfmanagement in most cases vary widely, often downright inept.

In the recent period the development of logistics services in medical activities, especially in the so-called hospital logistics has been observed. In the case of Poland this development is a consequence of the privatization of hospitals. Private entities in the era of high competition must ensure cost optimization and help them in the logistics operators. The examples of hospital logistics in countries where such services are provided show that hospitals using the services provider specializing in the handling can expect a reduction of logistics costs by up to 25 percent.

Of course, an independent logistics in some units works perfectly, but in the case of larger hospitals with successful optimization of logistics processes it could be more efficient and bring much greater cost savings through cooperation with logistics operator.

The complexity of the areas of the hospital needs clarification of many ranges of services. The basis is a logistics consulting and building a good relationship with the client.

The operator must be well- versed on fulfilling future requirements of the hospital. For this purpose, it should explore the possibility of standardization of products and suppliers for the entire hospital and customize workflows. Additionally, the needs of technical and human resources need to be assessed as well as the necessary changes formulated, the implementation of which is necessary to introduce efficient logistics processes.

The operator may also be responsible for the transportation of tools for sterilization in special heated vehicles, as well as support for the so-called cold chain (medications transported in special cold rooms). All these activities also support the logistics of hospitalization involving the sourcing various departments of the hospital, collecting and delivering the products and the implementation of specific solutions in cooperation with hospital service.

The paper presents the modern forms of logistics used in healthcare. The identification of the effects occurring as a result of the introduction of modern forms of logistics in healthcare was also carried out. A significant share of attention in the article is devoted to the supply chains based on modern means of transport.

\section{LOGISTICS TASKS IN HEALTHCARE}

The primary task of all hospitals is to improve the health of patients. In a typical hospital, a large number of people lead logistics operations often without being aware of it. And in most cases they are not appropriate people. For example, it is estimated that the nursing staff is dedicating an average of $10 \%$ of the time for logistical activities instead of looking after the sick. This affects not only the cost but also the effects of such care. Moreover, in countries where there is a shortage of health workers and social care it also affects the growth of stress-related illnesses among this group of workers.

Provision of medical services and patient care are essential processes in the hospital, which create a demand for support services related to patients (background processes). These secondary processes can be medical or non-medical. In addition, there were also 
identified services which are referred to as service processes. These processes are not directly related to the patients, but they are necessary for the proper operation of the healthcare facility.

Hospital logistics coordinates inter-ward movement of goods and information as well as part of the care of the patient. The examples of hospital logistics can be found in the supporting processes and services:

- logistic tasks related to patient through medical secondary processes supporting logistics patients: management of medicines, laboratory logistics management, medical products, sterile products, logistics, information and documentation, disposal of hazardous waste.

- tasks related to logistics processes, supporting non-medical secondary processes: management of food, bedding and bed management.

- logistics tasks associated with service processes: administrative management, mail handling, disposal of non-hazardous waste.

Fig. 1 Logistics processes in a hospital

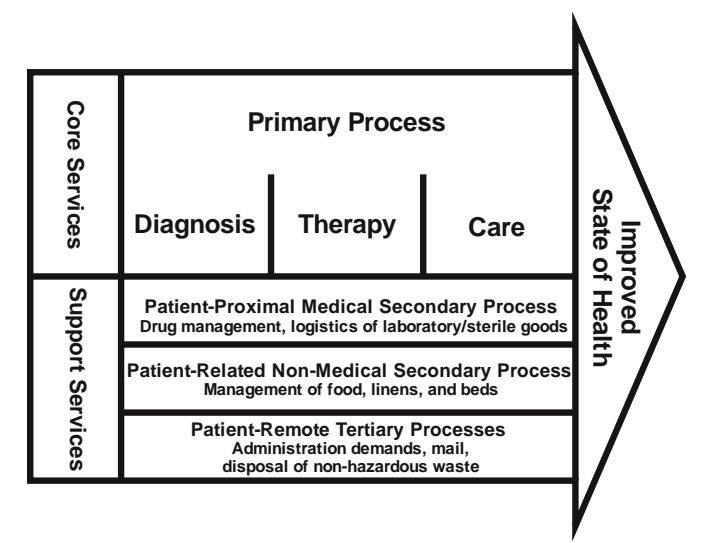

In many processes of hospital logistics material transport plays a decisive role. As required the hospital transportation of materials is either planned or the process is carried out on demand. Compared to industrial applications, the quality of the transport of materials in healthcare must be the highest. Incorrect or inaccurate deliveries can have fatal consequences for patients, hospital staff and visitors. An important roles in logistics plays also a hospital medicines management process. Conventional management of medicines in hospitals is usually a manual process. Daily preparation of drugs for the individual patient is performed by nurses on the wards. Therefore, in hospitals there are numerous drug storages located on the respective wards. Moreover, the manufacturing processes in the hospital pharmacy are characterized by manual handling. Automatic management of medicines in hospital pharmacies and hospital wards support and enhances patient safety.

It is estimated that as many as $46 \%$ of the total operating budget of the hospital is spent on activities related to logistics. Of this number, $27 \%$ is for materials and equipment, and $19 \%$ on labor. Labor costs include not only the staff associated with professional logistics but also health professionals. 


\section{MEANS OF HOSPITAL TRANSPORT}

In hospitals a number of different forms of transport is used. This can be integrated or not integrated transport, in many cases the individual one. Due to the technology used it can be distinguished air transport in the respective tubes, overhead rail transport, manual transport involving personal handling of the selected materials and transportation by using all kinds of wheeled carts. The first three transport technologies are used to transport light materials. Plastic tube used in pneumatic transport can transfer downloaded content to analyze and fine documentation. Overhead rails are designed for carrying small loads such as patient records, test results, laboratory testing or a blood sample. In many cases they are also used to carry heavier loads and more delicate components, such as glass containers. Also, it allows the circulation of several containers at the same time in several directions. Compared to a pneumatic transport this one is slower. Transportation of goods from one end of hospital to the other one takes about 15 minutes. In the case of pneumatic tubes this time is counted in seconds. In the transport where wheeled vehicles are used the more common are automatic guided vehicles to transport the AGV and mobile robots. $\mathrm{AGV}$ is intended in most cases for the transportation of materials and weight of up to $1000 \mathrm{~kg}$. Using the automatically guided vehicles transport one can reduce the load on the hospital staff, as well as improve the performance, availability and reliability of the transport system. AGVs also contribute to a reduction in operating costs of transport.

AGVs currently used in hospitals use laser or magnetic navigation. They are so intelligent and flexible that reach the individual branches using both horizontal distributions (corridors) and vertical (lift). If necessary, they may communicate with the control center at any time. In addition, they are equipped with sensors for detection and identification of cargo. AGV carry supplies and waste to and from different areas of the hospital complex, often at different levels. AGVs support hospital wards, kitchen, pharmacy, laundry, research departments, cafeteria and other areas.

In case of automatic means of transport the main applications of the AGVs are:

- Transportation of meals and return dirty dishes to the kitchen, Transport of sterile operating equipment and the return of dirty carts for decontamination,

- Provision of general materials (by weight) from the loading dock to the center of the supply and distribution when needed for the floors to patients or deliveries of linen, uniforms and medical supplies directly from the dock,

- Disposal of waste - handling waste streams (general, recyclable, medical) from all areas of the hospital to the recycling center,

- Provision of clean sheets and return to laundry or dock. The use of exchange carts allows to maximize the efficiency of the transport of both clean and dirty materials. Transport of drugs relies on the safe delivery of drugs from the dock to the center of the supply, or daily medications to nursing levels using a secure access for cars. Washing the carts consisting in the use of automatic dishwashers and dryers

- Automatic landing - increasing automation of AGV with optional automatic unloading of garbage or soiled bedding. [9]

The first AGV vehicle which was used in a hospital environment was HelpMate. It was used in 1991 in Danbury Hospital, where it was used to transport objects of small sizes. The vehicle used dead reckoning (odometry) and natural landmarks (walls of the corridor). HelpMate was one of the first robots (vehicles) which was used for 
transportation in a populated environment and is considered a pioneer in the field of hospital management. HelpMate is currently a registered trademark of Cardinal Health, Inc.

Subsequent vehicles operating on a similar principle as the HelpMate was I- Merc which specialized in the transport of food and Care- O- Bot which was designed to assist the elderly and requiring special assistance [1]. In recent years, many companies took up production of commercial vehicles for the hospital transport. The most well-known European manufacturer of such systems is Swisslog. It features, among others, TransCar system, which consists of AGVs which use the laser navigation and are able to carry loads of up to $450 \mathrm{~kg}$. The vehicles carry cargo in specially designed containers under which the vehicle enters. During transport, the container is raised. The disadvantage of this system is that it can carry simple elements such as documentation, medication, food. Swisslog also produces a small autonomous vehicles designed to transport inter-ward cargo weighing about $25 \mathrm{~kg}$ - RoboCourier. Another vehicle used in hospitals is TUG by Aethon company. It is a vehicle very similar to RoboCourier .

It was designed for the transport of various materials such as trays for meals, medications, linens, blood samples, medical records. It is able to carry cargo weighing up to $250 \mathrm{~kg}$. Another vehicle of the Aethon is Homer. Homer moves within the hospital and uses RFID technology and checks whether the equipment in the form of beds, wheelchairs and baskets are in the right place. Homer works with the TUG vehicles. If the equipment is recognized in the wrong place the information is sent to the TUG, which transports the item to its destination. The disadvantage of this system is the use of a special carriage baskets which increases the cost of installation and require a much larger number of changes in logistics hospital compared to the Swisslog [4].

Another company specializing in the production of the AGVs is FMC Technologies which offers ATLIS vehicle. It is a system very similar to Transcar but intended to transport much heavier loads. The system is used to collect, transport and deliver materials from the distribution center to individual areas of users, and vice versa back of baskets from different areas of the distribution center.

At present, the aforementioned companies are only a part of the existing commercial suppliers. Depending on the provided transport for work, there is a whole range of vehicles of various structures used to implement the transport tasks. The examples of these types of vehicles are shown in Figure 2.

Fig.2. Types of AGV vehicles
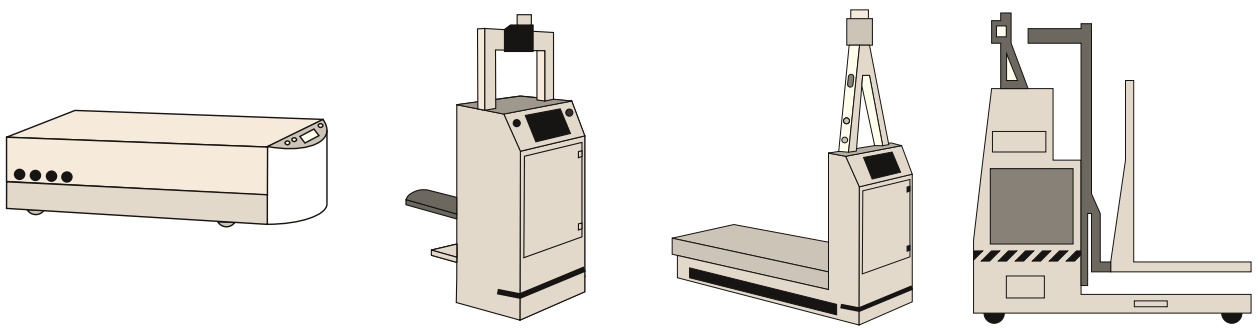
Individual systems supplied by companies operating on the market but differ with properties and functionalities which is shown in the following tables. Some of the vehicle do not have all the before mentioned functionalities and they were described as $\mathrm{a} / \mathrm{n}$.

Tab. 1 Transportation functionalities

Own study based upon [4]

\begin{tabular}{|c|c|c|c|c|c|c|}
\cline { 2 - 7 } \multicolumn{1}{c|}{} & HelpMate & Swisslog & Hospi & Aethon & SpeciMinder & RobCab \\
\hline $\begin{array}{c}\text { specific goods } \\
\text { transportation }\end{array}$ & - & - & + & - & - & - \\
\hline $\begin{array}{c}\text { varied goods } \\
\text { transportation }\end{array}$ & + & - & + & - & + & + \\
\hline $\begin{array}{c}\text { carry carts on its } \\
\text { body }\end{array}$ & - & + & - & + & - & - \\
\hline tow the carts & - & - & - & - & - & + \\
\hline
\end{tabular}

Tab.2 Functionalities of logistic systems

Own study based upon [4]

\begin{tabular}{|c|c|c|c|c|c|c|}
\cline { 2 - 7 } \multicolumn{1}{c|}{} & HelpMate & Swisslog & Hospi & Aethon & SpeciMinder & RobCab \\
\hline $\begin{array}{c}\text { group of robots } \\
\text { cooperation }\end{array}$ & + & + & + & + & - & + \\
\hline $\begin{array}{c}\text { supervisory } \\
\text { system }\end{array}$ & - & + & + & $\mathrm{n} / \mathrm{a}$ & - & + \\
\hline $\begin{array}{c}\text { ordering on robots } \\
\text { platform }\end{array}$ & + & - & $\mathrm{n} / \mathrm{a}$ & - & + & - \\
\hline $\begin{array}{c}\text { ordering through } \\
\text { logistic system }\end{array}$ & - & + & + & $\mathrm{n} / \mathrm{a}$ & - & + \\
\hline $\begin{array}{c}\text { task } \\
\text { scheduling }\end{array}$ & - & $\mathrm{n} / \mathrm{a}$ & $\mathrm{n} / \mathrm{a}$ & $\mathrm{n} / \mathrm{a}$ & - & + \\
\hline $\begin{array}{c}\text { automatic elevator } \\
\text { service }\end{array}$ & + & + & $\mathrm{n} / \mathrm{a}$ & + & + & + \\
\hline $\begin{array}{c}\text { artificial } \\
\text { landmarks }\end{array}$ & - & - & - & $\mathrm{n} / \mathrm{a}$ & - & - \\
\hline $\begin{array}{c}\text { system installed in } \\
\text { hospital }\end{array}$ & + & + & + & + & + & - \\
\hline
\end{tabular}

Hospital transport processes can be planned or spontaneous. For example, the transport of drugs, specimens and blood products, or sterile goods requires an immediate response. And the planned transportation of materials is usually for larger amounts of materials in special containers. Typical logistics processes with regular transport of concern include transport of food, bedding or waste. Currently, manufacturers of transportation systems intended for hospitals to offer automated material handling systems for both on-demand and scheduled for transportation. These systems are designed for hospital environment, where sterility and transport of highly sensitive products must be taken into account.

Most hospitals in the world, by introducing new technologies for the transport of hospital, decide to implement transportation systems which include AGVs as well as other 
technologies that, compared to the AGV are designed for transporting lighter materials (overhead rail systems, pneumatic tubes and small vehicles (mobile robots)).

\section{EXAMPLES OF APPLICATIONS}

Automatic transport systems are used in most developed countries with high labor costs. In French hospitals, an example of which is the François Quesnay hospital, the presence of automatic guided vehicles (AGV) for the transport of heavy loads can be observed. AGVs transport integrate medical and pharmaceutical agents, meals, bedding and waste. These vehicles move through dedicated corridors located in the basement and elevator. Their plan is programmed in accordance with the schedules of distribution of individual units. Each basket that is carried, has a unique identifier and destiny. The sample François Quesnay Hospital ( 20 wards, 400 beds) has on its equipment 6 AGV wheelchairs which carry per day 25 baskets of waste, 25 with medical and pharmaceutical, 25 with sheets and 17 with cold meals. For transporting smaller loads, the mobile robots are used. The area of their application is the transport of acts of patients, the results of tests and pharmaceuticals and they are the addition to the regular distribution (hospital CHU de Montpellier). An example of their use is the transfer between pharmacies and offices in the evenings and at the weekends. Robots have different routes to be programmed (source -target). They are equipped with sensors that allow them to choose the appropriate corridors and elevators.

However, the AGV vehicles are of the greatest interest of hospitals as the examples in the later part of the chapter are shown.

The first of these examples is the FN Motol Hospital in Prague. While designing the hospital, an effective solution for internal transport had already been sought. It had been decided to use the AGV vehicles as they provide to achieve full automation and flexibility. A ten-storey building has a special elevator for transport purposes. The hospital is equipped with 28 AGV vehicles that carry beds, laundry, medication, etc. Generally speaking, they support large flow to and from the wards. The transport system comprises a total of 16 points of distribution (among others, laundry, kitchens, sheets storage, pharmacy and distribution of stocks). Goods are collected and stored in 400 locations. They are also transported to and from the adjacent children's hospital by an underground tunnel. The system provides a transportation route corresponding to about $500 \mathrm{~km}$ per day. Goods are transported in three types of containers and the beds are also transported. For return transport from the wards it is not necessary to give the destination. AGV vehicle identifies transported goods itself and determines its destination. An integrated computer system for hospital management supervises the work of vehicles and provides an optimal flow. For example, the priority is to transport food when it takes place at mealtime. Priority is also considered in the case of movement at high and low top. AGV vehicles are collected when they no longer perform any task and they have not been allocated to another. [3]

Another hospital in which the system of AGV was introduced is Forth Valley Hospital in Scotland. This is a new hospital with new installations and has 860 beds. The AGV system of ATLIS was implemented there and it consists of $12 \mathrm{AGV}$ vehicles capable of transporting carts and baskets. In case of these vehicles, a laser navigation was used. The transport system includes distribution points such as: kitchen, laundry, materials and waste center. The hospital has 9 lift shafts. AGV vehicles of ATLIS have also been 
implemented in new hospitals in Castile and Leon (Spain). For example, a newly built hospital in this region featuring 600 beds was equipped with 6 vehicles using laser navigation. These vehicles carry 300 transport tasks a day. The transport system includes distribution points such as: kitchen, laundry room, sterilization center, waste center and pharmacy. The hospital has four lift shafts.

AGV systems are also used in German hospitals. As an example of it can be the University Clinic Friedrich-Schiller-Universität in Jena/Germany. The Gmbh system of MLR was used there. It is used to transport supplies and waste to and from different areas of the clinic often located on different levels. The system supports hospital wards, kitchen, pharmacy, laundry, research units, canteen and other areas. The system uses 26 vehicles fitted with a platform lift trucks and 400 containers transporting food, medicine, laundry, sterile materials, medical devices and waste. Each container has a bar code that is then read by the AGV vehicle so that the control system, that manages not only vehicles but also can track the location of each container. A specific feature of the system is that it also works in the neighboring buildings, providing and taking the appropriate materials.

One of the largest hospital complexes using AGV vehicles is the Cleveland Clinic in USA. The clinic includes 26 institutes of health, 1300 beds, 3.3 million of patient visits and more than 50000 admissions per year. Internal transport system using AGV vehicles was implemented in 2008. The system provides materials for five wards. These are: drugs, surgical kits, meals, linens, materials and supplies for nurses. They are delivered in total to 14000 employees located in the area of 168 acre campus.

The clinic introducing new solutions in hospital logistics has set several goals:

- Centralizing of materials management: which means that the materials necessary for the different units and different applications (medications, sheet, food and waste) are managed by one central point of management. Central warehouse is located in the basement of the hospital connected with the rest of the complex numerous underground passages.

- The study of a system that can handle both vertical and horizontal movement. Since the warehouse is underground, the system must manage the supply of materials to the warehouse or central areas of the warehouse level (horizontal movement) and then must keep track of the flow of materials to specific wards and/or individual floors (vertical movements).

- Ensuring rapid response capability. The clinic aims to provide several days of inventory for most products and fast replenishment if needed.

- Scaling up and down depending on the number of patients. It is difficult to predict in which period and for which number of patients the system should be oriented. Therefore, it is necessary to introduce the possibility of scaling both up and down. The primary objective was to create a system of support for materials handling 1300 beds in the main campus. The initial plan provided downloading about 30000 materials per day. Currently, the system supports an average 70000 downloads of materials per day raising to 150000 downloads a day on the peak days.

- Implementation without switching off. The clinic operates 24 hours a day 7 days a week. Implementation of a system must take place without interfering and interrupting its work.

The heart of the system is a fleet of AGV vehicles, capable to carry $1000 \mathrm{~kg}$ of materials each. No matter which ward the goods are to be carried they are packaged to the baskets in a central warehouse which are then transported by AGV vehicles through 
underground tunnels to the relevant points where the appropriate clinic staff responsible for the transport of materials is taking them and delivers to the right floor and wards. AGV vehicles are equipped with RFID readers that scan tags in the bottom of each basket. Using the scanning AGV vehicle checks if it has an appropriate basket to carry. RFID tags allow to keep track of AGV when travelling through the underground tunnel. The clinic has also installed RFID readers at the entrance to the landfill. RFID tags are also used for small valuables. If any of these items will be thrown into the waste bin or the dirty linen, RFID reader identifies it before being thrown away. The clinic also installed battery charging stations throughout the system of underground channels and the area of the warehouse.

\section{THE EFFECTS OF TRANSPORT AUTOMATION}

Automatic transport systems applied in hospitals have been used for at least a dozen years. Thus, there is data in various sources concerning the operation of these systems [2,5]. These data however, are incomplete and usually focus on selected areas of working. They mainly relate to economic and sanitary-epidemiological aspects of studies. The introduction of automated transport systems reduced the risk of infection. Traditional hospital transport equipment (hand carts), elevators or the doors are a potential source of infection. The introduction of AGV vehicles that are easy to clean, automatic doors and elevators reduced the risk. When considering economic factors, a good example is the work [6,7] analyzing on the simulation models, benefits from the introduction of automated transport system in University Hospital of Virginia. In [6] work, three scenarios had been established. The first one assumed that robots only serve the clinical laboratory. In the second scenario only hospital pharmacy was assumed to be served. The third scenario assumed the service of laboratory and pharmacy. In each of them the reduction of the human factor in logistics service achieved favorable economic effects. The greatest benefits however, reached the third scenario assuming laboratory and pharmacy services. For the purposes of the stimulation, a model of transport system was developed, consisting of six robots transporting pharmaceuticals and clinical laboratory samples. In this model, six connections were created, one in each floor. In each transport cycle, the vehicle visited clinical laboratory and pharmacy. In the first stage of the study, it had been established to replace all 22 employees by a fleet of six vehicles. The conducted simulations showed that the use of a fleet of 6 vehicles for both laboratory and pharmaceutical supplies causes $63 \%$ reduction in costs and $34 \%$ decrease in the duration of the entire cycle. The next step assumed the liquidation of 14 day jobs and keep one for a change. Obtained results caused $45 \%$ decrease in costs.

The work has also defined the necessary level of operating personnel reduction for which the automation of transport system is becoming profitable. The analysis showed that satisfactory results can be obtained when reducing the number of employees in a number of at least 9 people. The resulting return of investment with a reduction of at least 9 workers was $12 \%$.

Data concerning the operation of the automatic transport system in Leipzig Hospital in Germany are also very interesting. The hospital uses Swisslog transport system. The expected stability of the transport system used in the hospital is at least 15 years. The system is characterized by low operating costs per year at the level of about $2-4 \%$ of investments. Thanks to introduction of the system, the costs of repairs of damages caused 
during the transport were also reduced. In such conditions a very favorable period of return of investments was achieved. The sample graph of return of investments for German hospital was shown in figure 3.

Fig.3 The return of investment for transport system Own study based upon [9]

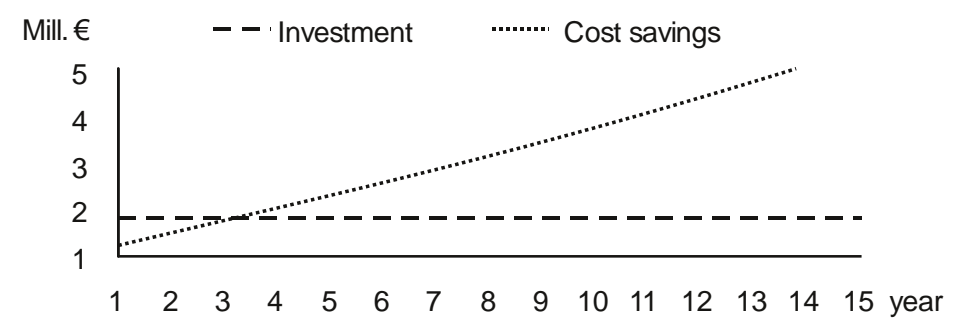

As in German hospital, the situation in American Memorial Hermann Southwest Hospital is the same. The payback period of the investment is very similar here. In most of the cases described in the literature, depending on factors such as human labor costs, the costs of investment, labor reduction scale, the payback period is in the range from 1,5 to 3 years.

Apart from purely economic reasons, in many cases the implementation of such a system has brought several additional benefits:

- AGV never get sick, do not need leave and also work at weekends,

- AGV are predictable and do not make human mistakes,

- AGV system can operate 24 hours a day 7 days a week,

- Hospital staff can concentrate on patients,

- Transport tasks can be scheduled and done on the night shift.

\section{CONCLUSIONS}

Hospitals are one of the most important organs in a modern society. Demographic factors such as the increase in the elderly population, need to verify the causes of heath care services in order to improve the operation of hospital, their effectiveness and efficiency.

The basic service provided by hospital is the patent care. To provide this service, there are a number of ancillary services that must be taken into account in hospitals. Although most of these services are invisible for the patient, they have a significant impact on the way patients experience a visit to hospital.

One of the main and usually underrated ancillary services in hospital is logistics. The main task of logical support for the hospital is to organize and maintain the flow of materials in the hospital. Hospitals require a huge variety of materials which often causes the formation of complex transport systems and complex material flow. New materials and devices have been developed for disposable use only and are more common. As a result, the transport volume expands significantly. More materials must be more often transported. 
Transport capacity can be improved by the introduction of automation. Implementation of transport tasks using people is usually limited by the physical capabilities of the staff. Automated transport systems may subject to much more flexible transport plans. Routes can be optimized and more frequent deliveries can be planned both at day and night. The speed of response to queries can also be improved if inventory tracking systems and transport systems are tightly integrated. To sum up, effectiveness of everyday processes in hospitals can be improved. The staff can save considerable amount of time which may be in turn given to patients. Therefore the quality of services provided to patients can be greatly improved.

\section{REFERENCES}

[1] Capezio F., Mastrogiovanni F., Scalmato A., Sgorbissa A., Vernazza P., Vernazza T., Zaccaria R., Mobile Robots in Hospital Environments: an Installation Case Study, 5th European Conference on Mobile Robots, Orebro Sweden 2011.

[2] Kriegel J., Jehle F., Dieck M., Mallory P., Advanced services in hospital logistics in the German health service sector. Logistics Research 6 (2013), 47-56

[3] NDC Information From Netzler and Dahlgren CO AB No 9

[4] Niechwiadowicz K., Zahoor K., Robot Based Logistics System for Hospitals - Survey, IRCSE '08: IDT Workshop on Interesting Results in Computer Science and Engineering, 2008 Sweden.

[5] Ozkil A. G., Fan Z., Dawids S., Aanaes H., Kristensen J.K., Christensen K.H., Service robots for hospitals: a case study of transportation tasks in a hospital, Proceedings of the IEEE International Conference on Automation and Logistics, Shenyang, China August 2009, 289294.

[6] Rossetti M.D., Felder R.A., Kumar A., Simulation of robotic courier deliveries in hospital distribution services. Health Care Management Science 3(2000) 201, 2013

[7] Rossetti M. D., Kumar A., Felder R. A., Mobile robot simulation of clinical laboratory deliveries. Proceedings of the 1998 Winter Simulation Conference, pages 1415-1422, 1998

[8] http://www.ssb.no

[9] http://www.swisslog.com

\section{NOWOCZESNA LOGISTYKA W SLUŻBIE ZDROWIA}

Podstawowym zadaniem wszystkich szpitali jest poprawa stanu zdrowia pacjentów. W typowym szpitalu ogromna liczba ludzi prowadzi działania logistyczne często nie będąc tego świadomym. Proces starzenia się społeczeństwa szczególnie widoczny w Europie przyczynia się do wzrostu obciążenia systemu ochrony zdrowia. Aby zapewnić żądany poziom usługi opieki zdrowotnej, kilka usług pomocniczych, takich jak logistyka, musi być skutecznie koordynowanych, aby zapewnić jakość i ciągłość opieki zdrowotnej.

Logistyka w działalności medycznej jest dziedziną, która nie jest widoczna dla pacjenta, ale bezpośrednio wpływa na jakość usługi zdrowotnej, przez co stanowi ważny dla organizacji ochrony zdrowia obszar zainteresowania. W większości przypadków logistyka szpitalna polegała do tej pory na doborze odpowiednich dostawców w poszczególnych obszarach działalności, począwszy od zaopatrzenia w leki, dostawców sprzętu, pralni, transportu do transplantologii aż na cateringu żywności kończąc. Takie podejście w samodzielnym zarządzaniu w większości przypadków przynosiło różne efekty, często wręcz nieudolne.

W ostatnim okresie czasu obserwowany jest rozwój usług logistycznych w działalności medycznej wykorzystujący zdobycze najnowocześniejszej techniki, zaliczyć tu można 
technologie informacyjne wspomagane zarządzaniem, bezobsługowe środki transportu, zautomatyzowany transport, technologie automatycznej identyfikacji.

$\mathrm{W}$ artykule przedstawiono nowoczesne formy logistyki stosowane w ochronie zdrowia. Wykazano korzyści wynikające ze stosowania tych rozwiązań. Korzyści te mogą być dwojakiego rodzaju. Z jednej strony obniżają koszty związane z funkcjonowaniem szpitala, z drugiej strony zapewniają wzrost bezpieczeństwa, niezawodności i dostępności o każdej porze. Znaczna część uwagi w artykule poświęcona została łańcuchom dostaw bazujących na nowoczesnych środkach transportu. Srodki te wykorzystywane są do transportu osób i materiałów.

Słowa kluczowe: służba zdrowia, ochrona zdrowia, logistyka w działalności medycznej, usługi logistyczne.

\section{DOI: 10.7862/rz.2013.mmr.28}

Tekst złożono w redakcji: wrzesień 2013

Przyjęto do druku: wrzesień 2013 